\title{
Industrial research booms in US, despite job cuts at large labs
}

[PHILADELPHIA] Despite the demise of the corporate research laboratory, industrial science in the United States is enjoying a resurgence, say research managers. It is being backed by Wall Street investors prepared to support long-term research that is on a par with the best work being done at universities and in rival companies.

Thousands of jobs have been lost at the central research laboratories of America's largest corporations over the past few years. But total research activity in US industry has been growing relatively strongly since 1994 . The real growth rate of 3 per cent per year in basic and applied research is slightly less than the 4.5 per cent growth seen in total research and development.

Speakers told a symposium on fundamental research and innovation in industry at last week's annual meeting of the American Association for the Advancement of Science that the new research activity is more widely dispersed, both between corporations and within them.

"A lot of research is not being done in big laboratories, but in small clumps of business start-ups," says Rita McGrath of the business school at New York's Columbia University. "A lot of money is flowing into start-ups."

The central research laboratories of many famous US corporations have been closed in recent years, or more tightly aligned to product development. But some observers believe that the overall level of innovation is higher as a result. The central laboratories, they say, tried too hard to replicate the environment of a university - in order to recruit scientists - and failed to address the needs of the corporations paying for them.

William Brinkman, vice-president for physical sciences at Lucent Technologies, says that his was the organization "most frequently accused" of pulling back from basic research. "We have changed and I don't regret it at all," he says.

According to Brinkman, Bell Laboratories - which Lucent has operated since it split from AT\&T - has returned to the emphasis on applied research which was the hallmark of its heyday. "Bell Labs in the 1950s was a very applied place," he says. By the 1970s it was far less so, "and by the 1980 s the Japanese were eating our lunch".

Brinkman says that today's research operation is "very similar" to that in the 1940s and 1950s. He says the laboratories are still doing good science and that their "interactions with the business side are as good as they've been in my 30 years there".

But not everyone is happy with the pat-



Brinkman: 'no regrets' at Lucent. tern Brinkman extols. Joseph Miller, vicepresident for research at DuPont, says: "I have a great concern that many of us are walking away from innovative technology and deciding to focus on very short-term applied technology, with short-term pay-offs".

Miller is unhappy that 70 per cent of basic research in the United States is now concentrated in the universities: he believes that technology often stimulates science, and that industry must drive this itself. "There are limitations to academic research as an alternative to industrial research."

Miller says government statistics indicate that research spending by US industry "has levelled off". But Chuck Larson, director of the Industrial Research Institute (IRI), a Washington-based organization supported by large corporations, says Miller's argument is based on outdated official statistics from the National Science Foundation (NSF).

"Often you hear that industry is farming out its innovation - but there has been a dramatic change in the data since the last NSF numbers were compiled," Larson says. IRI collects information more quickly and reports that basic and applied research in industry has been increasing by 3 per cent a year in real terms since 1993. "I talk to a lot of people, and [large corporations] are doing as much fundamental research as ever."

Different sectors have, of course, taken different approaches. In the oil industry, where prices have fallen to pre-1974 levels of around $\$ 16$ a barrel, the retrenchment in corporate research may have changed atti- tudes for good. Ed Witterholt, innovation hunter for BP, the largest oil producer in the United States, says: "If the oil price went back to $\$ 35$ a barrel and someone said 'let's start doing big research programmes like we did before', we wouldn't do it, because we've changed our religion."

These days, BP depends on suppliers such as Schlumberger for technological innovation. In its own business of oil exploration and production, it collaborates with oncefeared rivals Chevron, Mobil and Texaco.

As Witterholt points out, 300 such collaborative arrangements have been registered with the Justice Department under a provision that exempts "pre-competitive research" from the strict anti-trust laws that normally stop US corporations from working too closely with their competitors.

Business schools and consultants, meanwhile, are telling research managers to frame their operations in terms that investors can understand. Herbert Eleuterio, a former US research manager now at the National University of Singapore, where he advises the government on innovation, says: "You need people with backbone to stand up and defend high-risk, high-reward projects." Philip Brodsky, vice-president for corporate research at Monsanto, says: "You have to have a powerful vision that you can convey to a stock analyst."

Neither of them accepts that short-term investors are selling industrial research short. "The health of the global industrial enterprise is robust," says Eleuterio. He adds that industry's main concern should be optimizing its links with government-funded research. As for its own efforts, he says: "I'm very optimistic; I think the private sector is going to do the right thing." Colin Macilwain

\section{Germany approves DNA tests for visas}

[MUNICH] Germany has agreed to accept DNA tests as proof of a blood relationship in visa applications. According to government officials, the move is intended to help Kurds from Turkey and Iraq who wish to join relatives granted political asylum in Germany but are often unable to produce documents acceptable to the authorities.

The idea was put to the German foreign ministry by the country's embassy in Ankara, where increasing numbers of Kurds have been applying for visas in recent months. The embassy began accepting DNA tests as proof of relationship last December. Since then, about 25 visa applicants have taken up the option. Applicants can choose whether to present documents or the results of a DNA test.

The test uses saliva samples from the visa applicant and his or her relative in Germany, and is carried out privately at the Institute for Forensic Medicine in Münster. Applicants must pay the DM600 (US\$332) cost.

Data from the test remain confidential between the institute and the applicant. "We can't find any ethical objection to this procedure," says Dirk Lanzerat, a biomedical ethicist from the Institute for Ethics in Science in Bonn. Burkhardt Roeper 